\title{
The Interactive Effect of Uncertainty Avoidance Cultural Values and Leadership Styles on Open Service Innovation: A Look at Malaysian Healthcare Sector
}

\author{
Farooq Ahmed Jam* \\ Global Illuminators, \\ Kuala Lumpur, Malaysia \\ Boon-Kwee Ng \\ Faculty of Science, University of Malaya, \\ Kuala Lumpur, Malaysia
}

\author{
Sharan Kaur Garib Singh \\ School of Business, Whitireia Community Polytechnic, \\ 450 Queen Street 1010 Auckland, New Zealand \\ Nosheen Aziz \\ Institute of Management Sciences, \\ The Women University Multan, Multan, Pakistan
}

\begin{abstract}
This cross-sectional study investigated the interactive effect of uncertainty avoidance cultural values and leadership styles (paternalistic, authentic and democratic) on open service innovation. Validation of the open service innovation scale in the Eastern context was another major objective of this research. Confirmatory Factor Analysis and cross-validation techniques revealed that Malaysian culture considers open service innovation on four dimensions instead of six dimensions proposed by Rangus, Drnovsek, and Di Minin (2013). Moreover, linear and multiple moderated regression analysis performed on a random sample of 422 medical professionals working in hospitals revealed that paternalistic, authentic and democratic leadership styles positively stimulate open service innovation. Malaysia is low uncertainty avoidance collectivist culture, so the results of this study empirically proved that a lower level of uncertainty avoidance would play its positive role to adopt open service innovation in the organization. The results of this empirical investigation are valuable for leaders, managers, and practitioners to understand how leadership and culture can influence the strategic orientation of open service innovation.
\end{abstract}

Keywords: Open service innovation, paternalistic leadership style, democratic leadership style, authentic leadership style, uncertainty avoidance

Received: 13 August 2018; Accepted: 11 September 2018; Published: 3 October 2018

\section{INTRODUCTION}

Leadership and culture have been determined as key factors influencing the process of change in the organization (Ahmed, 1998; Nahavandi, 1993; Kotter, 1998). Numerous studies claimed innovation as a driving force for change whereas leadership and culture are considered as a key determinant of innovation (Damanpour, 1991; Elenkov \& Manev, 2005; Ogbonna \& Harris, 2000; Scott \& Bruce, 1994; Turner, 2008). Advancement of research from innovation to open innovation by $(\mathrm{H}$. W. Chesbrough, 2006) and further advancement in this stream of research leads to the introduction of the concept of open service innovation by (H. W. Chesbrough, 2011). Open service innovation is a framework that incorporates knowledge-based ideas from inside as well as outside the organization to gain sustainable competitive advantage in the market (Neyer, Bullinger, \& Moeslein, 2009; Rego, Sousa, Marques, \& e Cunha, 2012; Teece, 2007). Although leaders stimulate the open innovation in all organizational functions by encouraging the

\footnotetext{
${ }^{*}$ Correspondence concerning this article should be addressed to Farooq Ahmed Jam, Global Illuminators, Kuala Lumpur, Malaysia. E-mail: jam_farooq@yahoo.co.uk

(c) 2018 The Author(s). Published by KKG Publications. This is an Open Access article distributed under a Creative Commons Attribution-NonCommercial-NoDerivatives 4.0 International License.
} 
employees for their innovative behavior (Jung, Chow, \& Wu, 2003). However, theoretical development in innovation research is biased as the majority of research scholars focused more on influential role of traditional leadership styles such as transformational leadership, transactional leadership style or participative leadership style on innovation (Kang, Solomon, \& Choi, 2015; Sarros, Cooper, \& Santora, 2008).

Aycan (2006) advanced the leadership theory by introducing some new leadership styles such as paternalistic, democratic and authentic leadership style and suggested to test the influential role of these leadership styles in different cultures as effectiveness of leadership styles varies with cultural context (P. W. Dorfman, 1996). Moreover, keeping in view the future recommendations of Amirul and Daud (2012) to investigate the effectiveness of different leadership styles in Malaysian culture and H. W. Chesbrough (2011) direction to study open service innovation in different cultural setting are the motivational references for this research.

According to Turner (2008) culture influences the success or failure of any business strategy. The cultural variation may also influence the tactics of leaders to use open innovation strategy as a source of competitive advantage for the firm. Pellegrini, Scandura, and Jayaraman (2010) argued that value co-creation in the case of open service innovation requires a higher level of cultural understanding on the leaders' part. Numerous researchers have studied that national culture influence the adoption of innovation in the organization (Antonakis, Avolio, \& Sivasubramaniam, 2003; Rossberger \& Krause, 2017; Van Everdingen \& Waarts, 2003). However, scarcity of empirical research-based knowledge on the influential role of social-cultural and leadership styles on deployment of open service innovation especially Eastern context (i.e., Malaysian culture) is the significance of this research.

It is argued that uncertainty avoidance aspect of culture measures the risk-taking attitude of the people (G. Hofstede, 1980) that plays a vital role in the implementation of open service innovation (H. W. Chesbrough, 2011). Testing the moderation of uncertainty avoidance between leadership styles and open service is itself an advance in the theory of leadership, culture and open innovation. This research provides key insight for future theory development and tried to fill the gap in prior research by testing leadership and open service innovation theories which are mainly developed and tested in Western cultures (Pellegrini et al., 2010).

Transformation of health sector requires incorporation of latest innovation approaches and strategies such as open service innovation in this sector that may help in fertilization of ideas from inside as well as from outside to meet the purpose of better health care delivery and to promote a healthy lifestyle (Bodin, Ozhikenov, A, \& Sergeenkov, 2015; Saputri \& Mulyaningsih, 2016). In this connection investigation of the open service innovation in health sector organizations seems logical and expected to bring key policy insights for the policy makers to support Malaysian national vision of 2020. Malaysian health sector reforms are the key attributes of $10^{\text {th }}$ Malaysian plan which declared health sector among National Key Economic Areas (NKEA). This contextual significance originated the motive to study constructs such as leadership styles, culture and open service innovation in Malaysian health sector.

\section{THEORY AND HYPOTHESIS}

Open service innovation is a concept that has attracted a lot of attention from both practical and academic research. H. W. Chesbrough (2011) defined open service innovation as "the use of purposive inflows and outflows of knowledge to accelerate internal innovation and expand the markets for external use of innovation" (p. 69). H. Chesbrough, Vanhaverbeke, and West (2014) introduced a new definition of open innovation as "a distributed innovation process based on purposively managed knowledge flows across organizational boundaries, using pecuniary and non-pecuniary mechanisms in line with the organization's business model "(p. 17). When applying this concept to the services sector, it was stated that the adoption of this concept into services helps businesses in growing the business ecosystems and in creating greater value for the customer for sustainable knowledge-based competitive advantage (Oh, Phillips, Park, \& Lee, 2016). Prior researchers have identified some of the key drivers of innovation in the organizations as well (Baskaran \& Mehta, 2016; Huizingh, 2011; Saputri \& Mulyaningsih, 2016). However, Lerner and Tirole (2002) reported that communities of open innovation rely profoundly on strong leadership to work efficiently and to resist rupture, divergence, and uncertainty. Similarly, Fleming and Waguespack (2007) also argued that the roles which are related to leadership are important aspects of social bodies that can be integrated to formulate a context of open innovation. Leaders encourage the followers for their innovative behavior, to enhance intellectual capital and knowledge-sharing (Gong, Huang, \& Farh, 2009; Putri, 2015; Von Krogh, Nonaka, \& Rechsteiner, 2012). This

human intellectual capital has a positive role in successful implementation of innovation practices of any organization (Delgado-Verde, Martín-de Castro, \& Amores-Salvadó, 2016). This study filled the gap by extending the innovation 
management research through the integration of leadership roles in this theoretical and practical framework of open service innovation particularly in Healthcare sector of Malaysia.

The generic definition of Paternalistic leadership style is "style that combines strong discipline and authority with fatherly benevolence" (Farh \& Cheng, 2000). Three distinctive characteristics of paternalistic leaders are (1) authoritarianism (2) benevolence (3) moral character. Authoritarianism refers to leader behavior of authority, power and control over followers. Benevolence refers to leader's concern for the well-being and care of followers. While the third dimension, moral character described the leader acts as a role model for their followers (Aycan, 2006; Farh, Cheng, Chou, \& Chu, 2006). Thus, the coexistence of benevolence, authority, and moral character in paternalistic leadership style reflect what Jackman (1994) referred to paternalism as "velvet glove "which is based on father-child relationship. Father has benevolent intentions towards his children and takes all final decisions that are in the best interest and according to needs of life. These attributes make this style successful in terms of outcomes in non-Western cultures such as in Asia (Aycan, 2006). In this research, the author tried to integrate this diverse perspective of paternalistic leadership style into a theoretical framework for successful implementation of open service innovation. Authoritarianism requires individuals to obey the rules and guidance by paternalistic leaders that may suppress the free atmosphere needed for open service innovation. Individuals are also reluctant to express their innovative ideas in such environment (Haibo, Xiaoming, Liluo, Wenquan, \& Chunping, 2008). In this leadership style, the individual in authority (leader) plays the role of a father (Fikret Pasa, Kabasakal, \& Bodur, 2001; Redding, Norman, \& Schlander, 1994) and encourages the employees to express their innovative ideas to participate in decision-making process. Thus, paternalistic leadership style promotes open service innovation in the organization. Based on the above literature support and arguments following hypothesis is suggested.

\section{H1: Paternalistic leadership style is positively related to open service.}

Lewin and Lippitt (1938) characterized democratic leadership to be the style which heavily relies on the decision making and involvement of a group. This inclusiveness and involvement in the decision-making process are linked to enhanced levels of satisfaction among followers (Foels, Driskell, Mullen, \& Salas, 2000). The special characteristics of democratic leadership which differentiate this style from other leadership styles include, involving the followers in the task, delivering the sense of ownership to them, always being open and available for all kinds of discussion regarding the role played by individuals (Dahl, 1989; Fishkin, 1991). According to Anderson (1959) democratic leaders share and exchange information and feedback with followers to keep their moral high for better productivity. Additionally, better and effective communication including feedback, friendliness, positive attitude and inclusiveness are described as basic attributes of a democratic style of leadership (Anderson, 1959; Avolio, Yammarino, \& Bass, 1991; Chemers, 1984; Luthar, 1996). According to H. W. Chesbrough (2011) open innovation as an important mechanism to bring innovative concepts through the free flow of knowledge at both internal and external level in the organization. Thus, encouraging and cooperative role of democratic leaders (Kuczmarski \& Kuczmarski, 1995) promotes the free flow of innovative ideas throughout the organization to foster the emergence of open service innovation in the organization. This type of leadership style is preferable in collectivist cultures and especially Eastern context. As Malaysia is considered a collectivist context according to G. Hofstede (1986) country ranking. Therefore, it is expected that a leader with democratic style will help the emergence of open service innovation in the organizations working in the Malaysian context. Based on above arguments and literary support following hypothesis is suggested.

\section{H2: Democratic leadership style is positively related to open service innovation.}

Authentic leadership style is newly emerging leadership style defined by (Avolio, Walumbwa, \& Weber, 2009) as “a pattern of transparent and ethical leader behavior that encourages openness in sharing information needed to make decisions while accepting input from those who follow." They defined two major attributes including (1) psychological aptitudes and a (2) positive ethical climate. These characteristics work as an input towards increased awareness, unprejudiced dispensation, an internalized inspiration (self-motivation) and transparent relationship between the leader and subordinates. These traits further lead towards enhanced self-development of the followers (Walumbwa, Avolio, Gardner, Wernsing, \& Peterson, 2008). Authentic leaders increase the psychological capabilities of their employees that may improve the self-confidence and trust of employees on their leaders (Antonakis et al., 2003; Ilies, Morgeson, \& Nahrgang, 2005). Authentic leaders also emphasize on openness to build an empowering workplace for knowledge sharing. They motivate their followers by providing them constructive feedback and acknowledging their interest and involvement in the decision-making process (Ilies et al., 2005; Wong \& Cummings, 2009). All these characteristics 
make authentic leadership style a suitable style for successful deployment of open service innovation. Authentic leaders demonstrate high ethical and moral values and enacting these behaviors inspire the employees for active engagement in work activities and innovation (Avolio, Gardner, Walumbwa, Luthans, \& May, 2004; Černe, Jaklič, \& Škerlavaj, 2013). Michie and Gooty (2005) suggested that authentic leadership involves benevolent actions including tolerance for others, treating others with respect, going extra mile for the group without any self-interests, and remaining open to other peoples are the major characteristics which makes this style relevant and effective for emergence and success of open innovation in the organization. By reporting the relationship between the open innovation and authentic leadership Avolio and Gardner (2005) believe that challenge to successfully managing open innovation can be met by an authentic leadership style. Therefore, this positive connection between authentic style of leadership and open innovation in the organization provides a logical reason to include this leadership style in this study. Cooper, Scandura, and Schriesheim (2005) also recommended investigating the role of authentic leadership that foster open innovation processes in the organization due to its resemblance with characteristics of open innovation. Thus, based on prior research and recommendations following hypothesis is suggested.

\section{H3: Authentic leadership style is positively related to open service innovation.}

G. Hofstede (1980) identified culture as "Programming of the mind that differentiate one group from another. "He differentiated the nations across the globe based on five dimensions (i.e., Individualism versus collectivism, Masculinity versus Femininity, Power distance, uncertainty avoidance, long versus short-term orientation). Uncertainty avoidance dimension of national culture concerns with how individuals deal with an uncertain situation and unpredictable future. According to G. Hofstede (1984) cultures in which individuals take the risk, and take openness to new experience as a positive challenge are categorized low on uncertainty avoidance index. Whereas those cultures where individuals don't take new challenges and risks, feel fear and avoid uncertain situations they are categorized high in uncertainty avoidance.

The leaders have a differential impact on outcomes in distinctive culture settings as culture affects the individual behavior as well as organizational behavior (G. J. Hofstede, 2000; Silahtaroglu \& Vardarlier, 2016). A research conducted by House, Hanges, Javidan, Dorfman, and Gupta (2004) and G. J. Hofstede (2000) explained that culture impacts the leaders' efficiency and effectiveness. Malaysian culture is collectivist (G. Hofstede, 1984) and more paternalistic in nature with a diversity of three different races (Malays, Indians and Chinese) which makes it an interesting study setting to test the cultural impact on organization practices and strategic outcomes (Bin Yajid \& Rahmat, 2015). Most of the research has highlighted the influential role of national culture on different leadership styles (Ag Budin \& Wafa, 2015; Dickson, Castaño, Magomaeva, \& Den Hartog, 2012; P. Dorfman, Javidan, Hanges, Dastmalchian, \& House, 2012) and on innovation (Ambos \& Schlegelmilch, 2008; Shane, 1993, 1995; Van Everdingen \& Waarts, 2003) in Western culture.

Open service innovation is phenomena which are affected by risk-taking attitude prevailing in national and organizational culture. This requires employees' behavior for going the extra mile and being open to the external environment. According to Mortara and Minshall (2011), adoption of open service innovation practices by different organizations depends on the cultural values. Such as individuals with higher level of risk taking aptitude are found to be more effective in implementing new practices as compared to those who are lower level risk takers (G. Hofstede, 1987; G. J. Hofstede, 2000). Similarly, the societies high on uncertainty avoidance discourage the challenging the status quo and ultimately don't create a favorable environment for successful deployment of open service innovation in the organization. According to Shane (1995) positive influence of uncertainty acceptances is based on the assumption that risk tolerance attitude and employees' acceptance of change in organizational processes and behavior are helpful for deployment of innovation. This argument is also supported by the number of studies conducted in the cross-cultural paradigm of research (G. Hofstede, 1991; Punnett \& Shenkar, 2004; Triandis, Kurowski, \& Gelfand, 1994). The leadership efforts to bring open service innovation is influenced by national cultural dimension uncertainty avoidance is based on the arguments that leadership styles (i.e., paternalistic, autocratic and democratic) are recommended in Malaysian cultural context and according to G. Hofstede (1980) Malaysia is low in uncertainty avoidance. Hence it is expected that low uncertainty avoidance will accelerate the positive influence of leadership styles on open service innovation in the Malaysian context. Hence following hypotheses are suggested.

H4a: National culture dimension uncertainty avoidance moderate the relationship between paternalistic leadership style and open service innovation. 
H4b: National culture dimension uncertainty avoidance moderate the relationship between democratic leadership style and open service innovation.

H4c: National culture dimension uncertainty avoidance moderate the relationship between authentic leadership style and open service innovation.

\section{METHODS}

\section{Sample and Data Collection Procedure}

A self-administered field survey was conducted in Malaysian healthcare sector organizations (Hospitals) based on personal references of one of the study authors. A cover letter attached with questionnaire explained the purpose and objective of this research to respondents and ensured the confidentiality of information. Each questionnaire contained four parts. First one contains the questions about leadership styles (i.e., paternalistic, authentic and democratic), second part measured the open service innovation construct while the third one taped response on the cultural dimension of uncertainty avoidance. In the last section, demographics information was collected. Data was collected from 422 full-time doctors working in 10 different hospitals located in different cities across Malaysia. These hospitals have 750 average bed capacity with average 300 employees working in each organization. Among these respondents 231(54.7\%) were male and $191(45.3 \%)$ were female with mean age of all respondents 29.8 years $(S . D=5.49)$. Among these 422 respondents $327(77.5 \%)$ were working in public sector hospitals, while remaining were working in private and semi-government hospitals having on average experience of 4.8 years' $(S . D=4.69)$. The qualification of the respondents was ranged from MBBS to Ph.D. and the average qualification was FRCPS. Among these respondents 200 (47.3\%) respondents were house officers, $160(38 \%)$ were medical officers, $46(11 \%)$ were lecturers and clinical specialists while $16(3.7 \%)$ respondents were consultants with administrative responsibilities.

\section{Measures}

All key constructs of this empirical study were measured using Likert-scale. Authentic leadership style, democratic leadership style, and uncertainty avoidance were measured using 5-point Likert scale ranging from $1=$ strongly disagree, and $5=$ strongly agree while paternalistic leadership style was measured using 6-point Likert scale ranging from $1=$ strongly disagree to $6=$ strongly agree and open service innovation was measured on 7 points Likert scale ranging from $1=$ strongly disagree to $7=$ strongly agree. Some of the items of open service innovation were also assessed on 7 points Likert scale ranging from $1=$ never to $7=$ always.

Paternalistic Leadership Style: The 5-items scale of Aycan (2006) was used to measure paternalistic leadership style. The sample item for measurement of paternalistic leadership style includes "The ideal boss is like a parent and "Managers should provide fatherly advice and directions to their subordinates". The Cronbach alpha value was found 0.78 from this study data.

Authentic Leadership Style: 16- items scale of Neider and Schriesheim (2011) for authentic leadership style used in this study. The sample item for measurement of authentic leadership style include "My leader describes accurately the way that others view his/her abilities", and "My leader shows consistency between his/her beliefs and actions". The reliability of the authentic leadership scale was found to be 0.91 from this study data. Democratic Leadership Style: 6 items scale for democratic leadership style developed by Neider and Schriesheim (2011) was used in current study. The sample items include "Leaders need to help subordinates accept responsibility for completing their work" and "It is the leader's job to help subordinates find their passion". The reliability of this scale was 0.76 from this study data.

As measures adopted in this study were developed in different culture and context of examination as compared to current study so it is mandatory to ensure whether these measures are valid and reliable to be used in the Malaysian cultural context. Bagozzi, Yi, and Phillips (1991) recommended confirmatory factor analysis as a superior technique to examine the construct validity of measuring instruments. The results of CFA for leadership styles (i.e., paternalistic, authentic and democratic) revealed that a three-factor model provided a better fit $\left(X^{2}=925.28, d f=282\right.$, Comparative Fit Index $(\mathrm{CFI})=.87$, Goodness-of-Fit Index $(\mathrm{GFI})=.86$, Incremental Fit Index $(\mathrm{IFI})=.87$, and Root Mean Square Error of Approximation (RMSEA) $=.07$ ) for current study.

Uncertainty Avoidance: The 6-items scale for uncertainty avoidance from culture value framework developed by (G. Hofstede, 1980) was used. The sample items include "It is important to closely follow instructions and procedures" and "instructions for operations are important". The Cronbach alpha value reliability of the uncertainty avoidance scale was found 0.80 from current study data. 
Open Service Innovation: The 25 items measuring the open service innovation having 6 dimensions were adopted from Rangus et al. (2013). These six dimensions include: inward IP licensing and external participation, outsourcing R\&D and external networking, customer involvement, employee involvement, venturing, and outward IP licensing.

The sample items for inward IP licensing and external participation includes "In our hospital, we believe that knowhow/technology we have bought can create new opportunities for the hospital" and "In order to acquire new knowhow/technology we cooperate with consultancy companies "and "We additionally award our employees if they bring external knowhow/technology that improves our service".

The CFA results revealed that in the non-Western culture such as in Malaysia, people considered open service innovation on four dimensions instead of six dimensions. These results are very important to bring the validated measure of open service innovation into the body of knowledge. A second-order confirmatory factor analysis was performed to see if all the four dimensions were loaded onto a single latent factor. The results yield a good fit for latent single-factor model for OSI $\left(\mathrm{x}^{2}=751.29, d f=243, \mathrm{CFI}=0.93\right.$, GFI $=0.88$, IFI $=0.93$. and RMSEA $=0.07$. Results revealed a mediocre fit value for the current study (MacCallum, Browne, Sugawara, 1996). Therefore, to create an overall OSI (open service innovation) average scores on all items were used such that a higher score reflects high OSI. The reliability for the whole 25 -item open service innovation scale was found to be 0.95 .

\section{Control Variables}

Some of the leadership styles are influenced by gender as a study by (Eagly, Johannesen-Schmidt, \& Van Engen, 2003) reported women leaders as more supportive as compared to their men counterparts and show more appreciating and rewarding behavior. On the other hand, men were reported to be more passive and transactional managers. Gender was controlled for analysis. One-way analysis (ANOVA) results with open service innovation revealed that job nature was not significantly associated with open service innovation while all other demographic variables such as hospital type, gender, employees, total experience, income etc. were significantly associated with open service innovation. So, all significant demographic variables were controlled for analysis.

\section{Common Method Bias and Multicollinearity Issue}

As this study is the cross-sectional in nature and all study variables are self-reported so there exists a chance of method bias that may lead towards type 1 and type II errors (Avolio et al., 1991; Podsakoff, MacKenzie, Lee, \& Podsakoff, 2003). Harman's one latent factor test and confirmatory factor analysis with non-rotated factor solution was used. The results showed that there were multiple factors emerging out of data set and for a single factor model majority of variance was not accounted because of one factor. This proved that there was no method bias exists in this data. To double check confirmatory factor analysis using AMOS for single factor model was performed. The results $\lambda^{2}$ $(87, d f=240)=\mathrm{GFI}=0.69 ; \mathrm{CFI}=0.48 ; \mathrm{IFI}=0.67 ; \mathrm{RMSEA}=0.17$ confirmed that there exists no issue of common method bias in the study.

Table 1 MULTICOLLINEARITY COEFFICIENTS

\begin{tabular}{lllll}
\hline & Model & & Collinearity Statistics & \\
\cline { 3 - 4 } & & & Tolerance & VIF \\
\hline 1a & $\begin{array}{l}\text { Paternalistic } \\
\text { Style }\end{array}$ & Leadership & 0.584 & 1.711 \\
& $\begin{array}{l}\text { Authentic } \\
\text { Style }\end{array}$ & Leadership & 0.584 & 1.711 \\
Paternalistic & Leadership & 0.595 & 1.681 \\
& $\begin{array}{l}\text { Style } \\
\text { Democratic } \\
\text { Style }\end{array}$ & Leadership & 0.595 & 1.681 \\
Democratic & Leadership & 0.595 & 1.681 \\
& $\begin{array}{l}\text { Style } \\
\text { Authentic } \\
\text { Style }\end{array}$ & Leadership & 0.595 & 1.681 \\
\hline
\end{tabular}


In addition, we checked for variance inflation factor values (Hair, Anderson, Tatham, \& Black, 1998) and the tolerance statistics (Osterlind, Tabachnick, \& Fidell, 2001) which measure the extent to which collinearity exists among predictor variables that may affect the precision of a regression model. VIF scores of less than 5 (Chatterjee \& Price, 1991) and tolerance scores above .10 (Hair et al., 1998) are typically considered acceptable. Results reported in Table 1 have shown that no multicollinearity issue between independent variables.

\section{RESULTS}

Descriptive statistics (mean, standard deviation), bivariate correlation and reliability values are illustrated in Table 1(See Apnedix). The results show that association of open service innovation was significant for all three leadership styles such as value of association for paternalistic leadership style was $(r=0.45, p<.01)$, for authentic leadership style was $(r=0.51, p<.01)$, and for democratic leadership style was $(r=0.46, p<.01)$. On the other hand, the association between uncertainty avoidance and open service innovation was $(r=0.45, p<.01)$.

\section{Hypothesis Testing}

Multiple hierarchical regression analysis was used to test the direct effect Hypotheses (1, 2, 3) as recommended by (Kastalli \& Van Looy, 2013). In multiple regression analysis control variables identified through ANOVA were entered in the first step followed by independent variables. The regression analysis results reported in Table 2 that hypothesized positive relationship between paternalistic leadership style and open service innovation (Hypothesis 1 ) was supported $\left(\beta=0.32, \Delta R^{2}=.08 p<.001\right)$. In addition, the positive relationship of authentic leadership style with open service innovation (Hypothesis 2 ) also proved significantly $\left(\beta=0.38, \Delta R^{2}=.11, p<.001\right)$ and hypothesized direct positive relation of democratic leadership style with open service innovation (Hypothesis 3 ) was also supported ( $\beta=0.38,\left(\Delta R^{2}=0.10, p<.001\right)$. Thus, all direct effects were proved significantly and revealed that $8 \%, 11 \%$ and $10 \%$ change in variance accounted in open service innovation was due to these three leadership styles respectively.

Table 2 REGRESSION RESULTS FOR LEADERSHIP STYLES AND OPEN SERVICE INNOVATION

\begin{tabular}{llll}
\hline & Open Service Innovation & & $\Delta R^{2}$ \\
Predictors & $\beta$ & $R^{2}$ & \\
\hline Step 1 & & 0.24 & \\
Control Variables & & & $0.08^{* * *}$ \\
Step 2 & 0.33 & $0.11^{* * *}$ \\
Paternalistic Leadership & $0.32^{* * *}$ & 0.36 & $0.10^{* * *}$ \\
Authentic Leadership & $0.38^{* * *}$ & 0.34 & \\
Democratic Leadership & $0.35^{* * *}$ & &
\end{tabular}

\section{Moderating Role of Uncertainty Avoidance}

Moderated multiple regression analysis was performed to test hypothesized moderating role of uncertainty avoidance (hypothesis $4 \mathrm{a}$ through $4 \mathrm{c}$ ) between leadership styles (paternalistic, authentic and democratic) and open service innovation. Moderated multiple regression analysis results presented in Table 3 revealed that interaction term of uncertainty avoidance and paternalistic leadership was significant for open service innovation $\left(\beta=-0.23, \Delta R^{2}=.016, p\right.$ $<.01)$ and explained $1 \%$ variance in open service innovation was due to this interaction term. Thus, hypothesis 4 a was proved. 
Table 3 MODERATION ANALYSIS OF NATIONAL CULTURAL DIMENSIONS BETWEEN PATERNALISTIC LEADERSHIP STYLE AND OPEN SERVICE INNOVATION

\begin{tabular}{|c|c|c|c|}
\hline \multirow[b]{2}{*}{ Predictors } & \multicolumn{3}{|c|}{ Open Service Innovation } \\
\hline & $\beta$ & $R^{2}$ & $\Delta R^{2}$ \\
\hline Step 1 & & & \\
\hline Control Variables & & $0.209 * * *$ & \\
\hline Step 2 & & & \\
\hline $\begin{array}{l}\text { Paternalistic Leadership } \\
\text { style }\end{array}$ & $0.239 * * *$ & & \\
\hline $\begin{array}{l}\text { Uncertainty Avoidance } \\
\text { Step } 3\end{array}$ & $0.448 * * *$ & 0.35 & $0.138 * * *$ \\
\hline $\begin{array}{l}\text { PLx Uncertainty Avoid- } \\
\text { ance }\end{array}$ & $-0.231 * *$ & 0.36 & $0.016 * *$ \\
\hline
\end{tabular}

Results reported in Table 4 depicted that interaction term of uncertainty avoidance and authentic leadership style was significant for open service innovation $\left(\beta=-0.25, \Delta R^{2}=.016, p<.01\right)$ and explained $1 \%$ variance in open service innovation. Thus, hypothesis $4 \mathrm{~b}$ is also significantly proved.

Table 4 MODERATION ANALYSIS OF NATIONAL CULTURAL DIMENSIONS BETWEEN AUTHENTIC LEADERSHIP STYLE AND OPEN SERVICE INNOVATION

\begin{tabular}{|c|c|c|c|}
\hline \multirow[b]{2}{*}{ Predictors } & \multicolumn{3}{|c|}{ Open Service Innovation } \\
\hline & $\beta$ & $R^{2}$ & $\Delta R^{2}$ \\
\hline Step 1 & & & \\
\hline Control Variables & & $0.209 * * *$ & \\
\hline Step 2 & & & \\
\hline $\begin{array}{l}\text { Authentic Leadership } \\
\text { style }\end{array}$ & $0.319 * * *$ & & \\
\hline $\begin{array}{l}\text { Uncertainty Avoidance } \\
\text { Step } 3\end{array}$ & $0.456^{* * *}$ & 0.37 & $0.164 * * *$ \\
\hline $\begin{array}{l}\text { ALxUncertainty Avoid- } \\
\text { ance }\end{array}$ & $-0.252 * *$ & 0.39 & $0.016 * *$ \\
\hline
\end{tabular}

Table 5 MODERATION ANALYSIS OF NATIONAL CULTURAL DIMENSIONS BETWEEN DEMOCRATIC LEADERSHIP STYLE AND OPEN SERVICE INNOVATION

\begin{tabular}{|c|c|c|c|}
\hline \multirow[b]{2}{*}{ Predictors } & \multicolumn{3}{|c|}{ Open Service Innovation } \\
\hline & $\beta$ & $R^{2}$ & $\Delta R^{2}$ \\
\hline Step 1 & & & \\
\hline $\begin{array}{l}\text { Control Variables } \\
\text { Step } 2\end{array}$ & & $0.208 * * *$ & \\
\hline $\begin{array}{l}\text { Democratic Leadership } \\
\text { style }\end{array}$ & $0.288 * *$ & & \\
\hline $\begin{array}{l}\text { Uncertainty Avoidance } \\
\text { Step } 3\end{array}$ & $0.398 * * *$ & 0.34 & $0.134 * * *$ \\
\hline $\begin{array}{l}\text { DLxUncertainty Avoid- } \\
\text { ance }\end{array}$ & $-0.225 * *$ & 0.35 & $0.013^{* *}$ \\
\hline
\end{tabular}


Lastly, the interaction term of uncertainty avoidance and democratic leadership style was also significant for open service innovation $\left(\beta=-0.22, \Delta R^{2}=.013, p<.01\right)$ explaining $1 \%$ variance as given in Table 5 .

Slop analysis was performed to further test the significance of interaction term for low and high $(M \pm S . D)$ of moderator uncertainty avoidance. The interaction plots are displayed in Figure 1, 2 and 3. Figure 1 shows that slop for low value of uncertainty avoidance was significant $(\beta=-0.40, p<0.05)$ for paternalistic leadership style and open service innovation. while interaction plot (Figure 2) shows that positive relationship of authentic leadership style and open service innovation will be stronger in case of low uncertainty avoidance $(\beta=-0.46, p<0.05)$. Similarly Figure 3 depicted positive association of democratic leadership style and open service innovation will be stronger when uncertainty avoidance is low $(\beta=-0.42, p<0.05)$. Hence these interaction plots support Hypothesis $4 \mathrm{a}, 4 \mathrm{~b}$ and $4 \mathrm{c}$ are fully supported according to slop analysis.

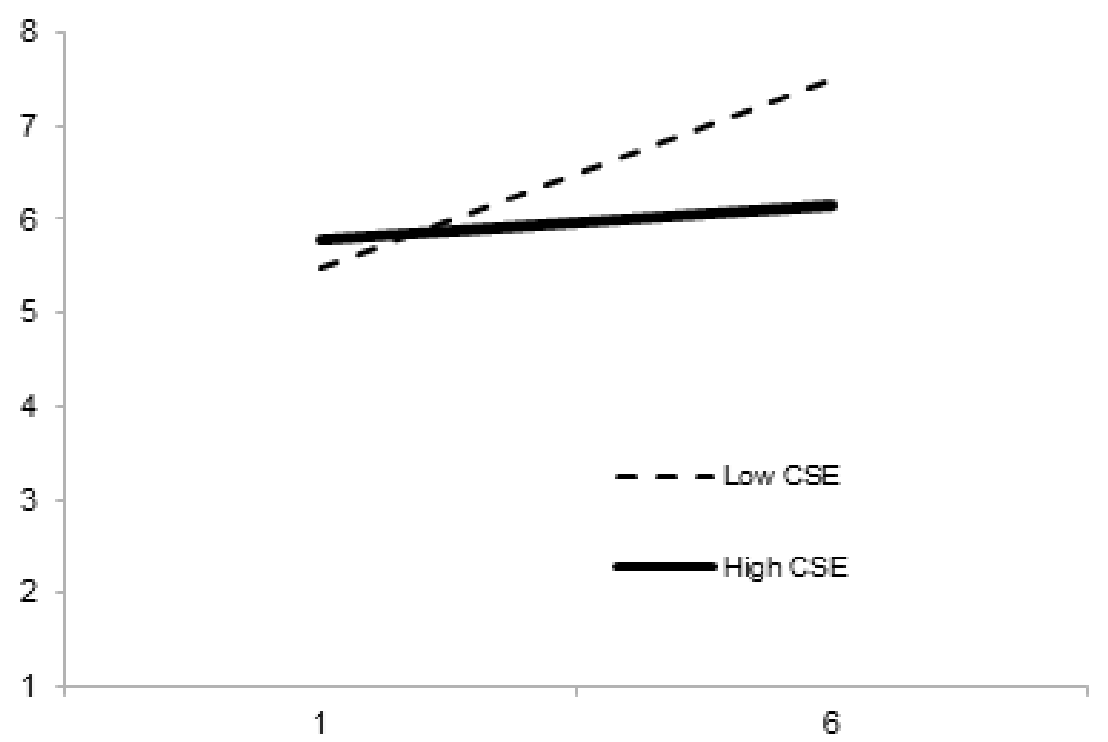

Figure 1 Interactive Effect of Uncertainty Avoidance and Paternalistic Leadership Style on Open Service Innovation

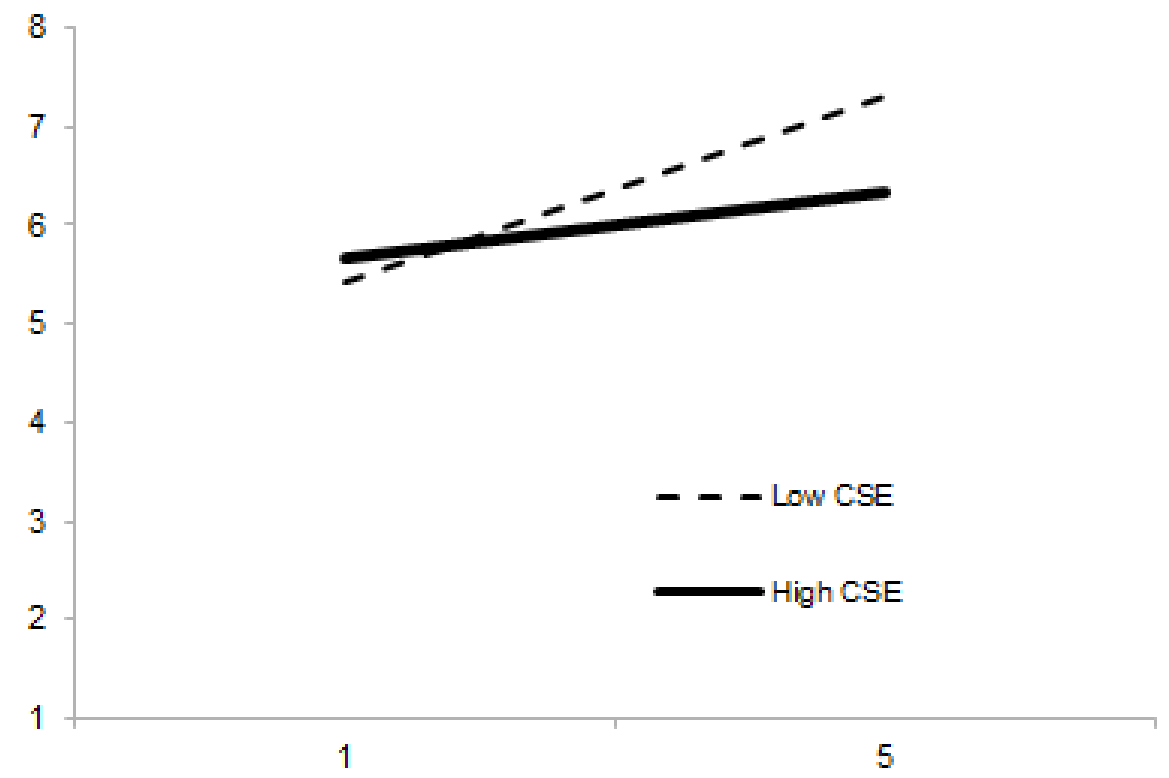




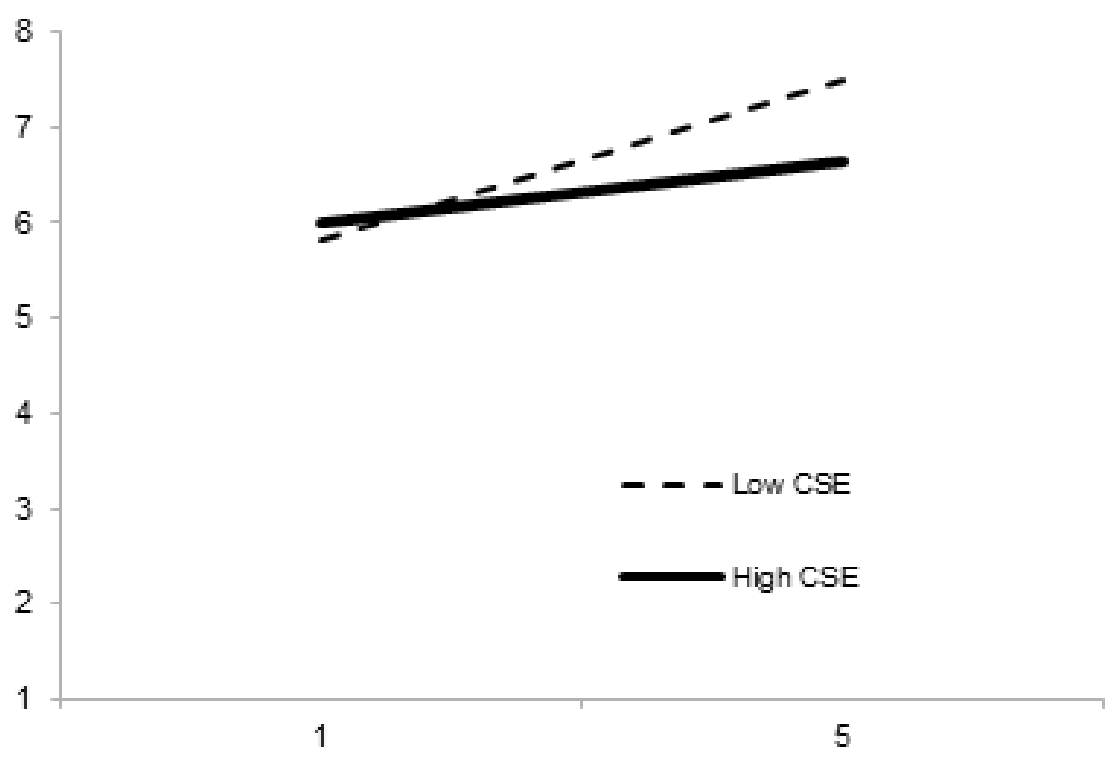

Figure 3 Interactive Effect of Uncertainty Avoidance and Democratic Leadership Style on Open Service Innovation

\section{DISCUSSION}

Despite of the past research on the influential role of leadership on innovation (Fleming \& Waguespack, 2007; Kang et al., 2015) and processes involve in the implantation of open innovation (Chiaroni, Chiesa, \& Frattini, 2011), this research made a unique contribution to leadership effectiveness and open service innovation theory by empirically testing the role of some newly emerging leadership styles (i.e., paternalistic, autocratic and democratic) on open service innovation in Eastern context especially in Malaysia. Furthermore, moderating role of cultural dimension uncertainty avoidance tested in this relationship is also an advance in the body of literature related to cross-cultural research.

This research has contributed to prior research in five different ways. Firstly, this research proved positive association of paternalistic leadership style with open service innovation in non-Western context is consistent with the notion that paternalistic leadership style is effective in non-Western culture (Pellegrini et al., 2010).

Secondly, this research proposed and proved that democratic leadership style is positively related to open service innovation in Malaysia. This empirical study proved a positive association between democratic leadership style and open service innovation is consistent with findings of (Kastalli \& Van Looy, 2013) that proved positive association democratic leadership styles with service oriented management style. According to H. W. Chesbrough (2011) adoption of service oriented management style is one of the major elements of open service innovation paradigm.

Thirdly this research also confirmed the positive relationship between authentic leadership style and open service innovation which is consistent with the findings of multiple studies which reported positive association between antecedents of open innovation and authentic leadership styles (Den Hartog \& De Hoogh, 2009; Rego et al., 2012; Elenkov \& Manev, 2005). This positive association of authentic leadership style and open service innovation also supported the previous results reported by (Avolio et al., 2004) that challenge of successfully managing open innovation can be managed through authentic leadership style.

Fourthly this research extended the previous research by uniquely providing the magnificent support to theories (mainly leadership and open service innovation theories) developed in a Western context for their generalizability in Eastern culture (i.e., Malaysia). According to Ag Budin and Wafa (2015) cultural-fit leadership style is crucial to align individual goals with organizational goals.

Empirically proved the moderating role of uncertainty avoidance is also in line with the previous notion that high uncertainty avoidance culture resists the innovative process in the organizations (G. J. Hofstede, 2000). According to G. Hofstede (1980), Malaysia is ranked as low uncertainty avoidance collectivist culture so the results of this study are consistent with previous notions that lower level of uncertainty avoidance will play its positive role to adopt innovation in the organization (P. W. Dorfman, 1996; G. J. Hofstede, 2000; G. Hofstede, 2006; Png, Tan, \& Wee, 
2001; Van Everdingen \& Waarts, 2003).This proved the influential role of uncertainty avoidance for establishing open service innovation is also consistent with the findings of Hayton, George, and Zahra (2002) who argued the low level of uncertainty avoidance facilitate the entrepreneurship.

\section{Managerial Implications}

The results of this empirical investigation are valuable for the leaders, managers, and practitioners to understand how leadership and culture can influence the strategic orientation of open service innovation. The findings of this study proved that in collectivistic societies such as Malaysia certain leadership characteristics and behaviors are very effective in establishing the open service innovation in the organization. So, organizations working in Eastern context in general and ASEAN context in specific can get insights from these findings to adopt leadership styles such as paternalistic, democratic and authentic for successful implementation of open service innovation.

The moderation of uncertainty avoidance between leadership styles and open service innovation provides insights for leaders and managers to be conscious of the cultural factors while making strategies and operational plans for any transformation including open service innovation. The findings of this research may also help the Malaysian human resource managers in health care sector as well as in other service sectors to design the practices for retaining the key human capital which will ultimately help to gain a sustainable competitive advantage.

\section{Limitations and Future Recommendations}

Although this study provides magnificent support to the proposed theoretical model, however, this study also has some limitations. Firstly, the data was collected only from hospitals of Malaysia. The generalizability of study may be increased by testing the proposed model in the overall health sector and also other service sectors. The second limitation is that in this study authors tested the moderating role of uncertainty avoidance only, it is recommended to test the moderating role of all cultural dimensions of (G. Hofstede, 1980). Lastly, future research should also consider some mediating mechanism between leadership styles and open service innovation to highlight their role in the process of change.

\section{CONCLUSION}

This study provides insights that how leaders efforts to establish open service innovation are influenced by macro-environmental factors such as national culture and proved the effectiveness of leadership styles mainly authentic, paternalistic and democratic in Eastern culture. Testing for leadership styles and open service innovation in Malaysian healthcare sector is another major advance by this research. This study provided a basic ground for further extension of an idea pitched in this framework. This framework has enormous potential to bring key policy insights in different sectors of the economy for sustainable competitive advantage.

\section{REFERENCES}

Ag Budin, D. K., \& Wafa, S. A. (2015). The relationship between culture and leadership style preference among Malay-Brunei, Bajau and Kadazan-Dusun community in Sabah, Malaysia. Journal of Management Development, 34(10), 1202-1210. doi:https://doi.org/10.1108/jmd-02-2015-0019

Ahmed, P. K. (1998). Culture and climate for innovation. European Journal of Innovation Management, 1(1), 30-43. doi:https://doi.org/10.1108/14601069810199131

Ambos, B., \& Schlegelmilch, B. B. (2008). Innovation in multinational firms: Does cultural fit enhance performance? Management International Review, 48(2), 189. doi:https://doi.org/10.1007/s11575-008-0011-2

Amirul, S. R., \& Daud, H. (2012). A study on the relationship between leadership styles and leadership effectiveness in Malaysian GLCs. European Journal of Business and Management, 4(8), 193-201. doi:https://doi.org/10.21275/ art20164228

Anderson, R. C. (1959). Learning in discussions: A resume of the authoritarian-democratic studies. Harvard Educational Review, 4(12), 34-50. doi:https://doi.org/10.2307/1338137

Antonakis, J., Avolio, B. J., \& Sivasubramaniam, N. (2003). Context and leadership: An examination of the nine-factor full-range leadership theory using the multifactor leadership questionnaire. The Leadership Quarterly, 14(3), 261-295. doi:https://doi.org/10.1016/s1048-9843(03)00030-4 
Avolio, B. J., \& Gardner, W. L. (2005). Authentic leadership development: Getting to the root of positive forms of leadership. The Leadership Quarterly, 16(3), 315-338. doi:https://doi.org/10.4135/9781446212752.n2

Avolio, B. J., Gardner, W. L., Walumbwa, F. O., Luthans, F., \& May, D. R. (2004). Unlocking the mask: A look at the process by which authentic leaders impact follower attitudes and behaviors. The Leadership Quarterly, 15(6), 801-823. doi:https://doi.org/10.1016/j.leaqua.2004.09.003

Avolio, B. J., Walumbwa, F. O., \& Weber, T. J. (2009). Leadership: Current theories, research, and future directions. Annual Review of Psychology, 60, 421-449. doi:https://doi.org/10.1146/annurev.psych.60.110707.163621

Avolio, B. J., Yammarino, F. J., \& Bass, B. M. (1991). Identifying common methods variance with data collected from a single source: An unresolved sticky issue. Journal of Management, 17(3), 571-587. doi:https://doi.org/ $10.1177 / 014920639101700303$

Aycan, Z. (2006). Paternalism indigenous and cultural psychology. Boston, MA: Springer.

Bagozzi, R. P., Yi, Y., \& Phillips, L. W. (1991). Assessing construct validity in organizational research. Administrative Science Quarterly, 36(3), 421-458. doi:https://doi.org/10.2307/2393203

Baskaran, S., \& Mehta, K. (2016). What is innovation anyway? youth perspectives from resource-constrained environments. Technovation, 52(17), 4-17. doi:https://doi.org/10.1016/j.technovation.2016.01.005

Bin Yajid, A. A., \& Rahmat, A. K. (2015). The challenge of ratification and application of specific regional based declaration for railway industry in ASEAN mainland: The national culture perspective. Procedia-Social and Behavioral Sciences, 172, 801-807. doi:https://doi.org/10.1016/j.sbspro.2015.01.435

Bodin, N. O., Ozhikenov, A. K., A, O. K., \& Sergeenkov, S. A. (2015). Problems of medical care in an emergency situation health insurance Kendari city, Indonesia. International Journal of Health and Medical Sciences, 1(2), 37-41. doi:https://doi.org/10.20469/ijhms.30003-2

Černe, M., Jaklič, M., \& Škerlavaj, M. (2013). Authentic leadership, creativity, and innovation: A multilevel perspective. Leadership, 9(1), 63-85. doi:https://doi.org/10.1177/1742715012455130

Chatterjee, S., \& Price, B. (1991). Regression analysis. New York, NY: Wiley.

Chemers, M. M. (1984). The social, organizational, and cultural context of effective leadership. Leadership: Multidisciplinary Perspectives, 91-112. doi:https://doi.org/10.4135/9781544308524.n11

Chesbrough, H., Vanhaverbeke, W., \& West, J. (2014). New frontiers in open innovation. Oxford, UK: Oup Oxford.

Chesbrough, H. W. (2006). Open innovation: The new imperative for creating and profiting from technology. Boston, MA: Harvard Business Press.

Chesbrough, H. W. (2011). Bringing open innovation to services. Sloan Management Review, 52(2), 85-90. doi:https://doi.org/10.5437/08953608x5402006

Chiaroni, D., Chiesa, V., \& Frattini, F. (2011). The open innovation journey: How firms dynamically implement the emerging innovation management paradigm. Technovation, 31(1), 34-43. doi:https://doi.org/10.1016/ j.technovation.2009.08.007

Cooper, C. D., Scandura, T. A., \& Schriesheim, C. A. (2005). Looking forward but learning from our past: Potential challenges to developing authentic leadership theory and authentic leaders. The Leadership Quarterly, 16(3), 475-493. doi:https://doi.org/10.1016/j.leaqua.2005.03.008

Dahl, R. A. (1989). Democracy and its critics. New York, NY: Yale University Press.

Damanpour, F. (1991). Organizational innovation: A meta-analysis of effects of determinants and moderators. Academy of Management Journal, 34(3), 555-590. doi:https://doi.org/10.2307/256406

Delgado-Verde, M., Martín-de Castro, G., \& Amores-Salvadó, J. (2016). Intellectual capital and radical innovation: Exploring the quadratic effects in technology-based manufacturing firms. Technovation, 54, 35-47. doi:https:// doi.org/10.1016/j.technovation.2016.02.002

Den Hartog, D. N., \& De Hoogh, A. H. (2009). Empowering behaviour and leader fairness and integrity: Studying perceptions of ethical leader behaviour from a levels-of-analysis perspective. European Journal of Work and Organizational Psychology, 18(2), 199-230. doi:https://doi.org/10.1080/13594320802362688

Dickson, M. W., Castaño, N., Magomaeva, A., \& Den Hartog, D. N. (2012). Conceptualizing leadership across cultures. Journal of World Business, 47(4), 483-492. doi:https://doi.org/10.1016/j.jwb.2012.01.002

Dorfman, P., Javidan, M., Hanges, P., Dastmalchian, A., \& House, R. (2012). Globe: A twenty year journey into the intriguing world of culture and leadership. Journal of World Business, 47(4), 504-518. 
Dorfman, P. W. (1996). International and cross-cultural leadership research. Handbook for international management research, 2. doi:https://doi.org/10.1007/978-1-137-24203-7_24

Eagly, A. H., Johannesen-Schmidt, M. C., \& Van Engen, M. L. (2003). Transformational, transactional, and laissez-faire leadership styles: A meta-analysis comparing women and men. Psychological Bulletin, 129(4), 569. doi:https://doi.org/10.1037/0033-2909.129.4.569

Elenkov, D. S., \& Manev, I. M. (2005). Top management leadership and influence on innovation: The role of sociocultural context. Journal of Management, 31(3), 381-402. doi:https://doi.org/10.1177/0149206304272151

Farh, J.-L., \& Cheng, B.-S. (2000). A cultural analysis of paternalistic leadership in chinese organizations. In Management and organizations in the Chinese context, New York, NY (pp. 84-127).

Farh, J. L., Cheng, B. S., Chou, L. F., \& Chu, X. P. (2006). Authority and benevolence: Employees' responses to paternalistic leadership in China. In A. S. Tsui, Y. Bian, and L. Cheng (Ed.), China's domestic private firms: Multidisciplinary perspectives on management and performance. New York, NY: Sage Publication.

Fikret Pasa, S., Kabasakal, H., \& Bodur, M. (2001). Society, organisations, and leadership in turkey. Applied Psychology, 50(4), 559-589. doi:https://doi.org/10.1111/1464-0597.00073

Fishkin, J. S. (1991). Democracy and deliberation: New directions for democratic reform. New York, NY: Yale University Press.

Fleming, L., \& Waguespack, D. M. (2007). Brokerage, boundary spanning, and leadership in open innovation communities. Organization Science, 18(2), 165-180. doi:https://doi.org/10.1287/orsc.1060.0242

Foels, R., Driskell, J. E., Mullen, B., \& Salas, E. (2000). The effects of democratic leadership on group member satisfaction: An integration. Small Group Research, 31(6), 676-701. doi:https://doi.org/10.1177/104649640003100603

Gong, Y., Huang, J.-C., \& Farh, J.-L. (2009). Employee learning orientation, transformational leadership, and employee creativity: The mediating role of employee creative self-efficacy. Academy of Management Journal, 52(4), 765-778. doi:https://doi.org/10.5465/amj.2009.43670890

Haibo, Y., Xiaoming, Z., Liluo, F., Wenquan, L., \& Chunping, L. (2008). How to lead the organizational learning: A relationship between paternalistic leadership and organizational learning. Science Research Management, 5(4), 242-270. doi:https://doi.org/10.1007/s11782-009-0013-3

Hair, J. F., Anderson, R. E., Tatham, R. L., \& Black, W. C. (1998). Multivariate data analysis. New York, NY: Prentice Hall International.

Hayton, J. C., George, G., \& Zahra, S. A. (2002). National culture and entrepreneurship: A review of behavioral research. Entrepreneurship Theory and Practice, 26(4), 33-52. doi:https://doi.org/10.1177/104225870202600403

Hofstede, G. (1980). Culture and organizations. International Studies of Management and Organization, 10(4), 15-41. doi:https://doi.org/10.1080/00208825.1980.11656300

Hofstede, G. (1984). Culture's consequences: International differences in work-related values. New York, NY: Sage.

Hofstede, G. (1986). Cultural differences in teaching and learning. International Journal of Intercultural Relations, 10(3), 301-320. doi:https://doi.org/10.1016/0147-1767(86)90015-5

Hofstede, G. (1987). The applicability of McGregor's theories in South East Asia. Journal of Management Development, 6(3), 9-18. doi:https://doi.org/10.1108/eb051642

Hofstede, G. (1991). Empirical models of cultural differences. New, York, NY: Swets \& Zeitlinger Publishers.

Hofstede, G. (2006). What did globe really measure? researchers' minds versus respondents' minds. Journal of International Business Studies, 37(6), 882-896. doi:https://doi.org/10.1057/palgrave.jibs.8400233

Hofstede, G. J. (2000). Organizational culture: Siren or sea cow? A reply to dianne lewis. Strategic Change, 9(2), 135-137. doi:https://doi.org/10.1002/(sici)1099-1697(200003/04)9:2<135::aid-jsc464>3.0.co;2-e

House, R. J., Hanges, P. J., Javidan, M., Dorfman, P. W., \& Gupta, V. (2004). Culture, leadership, and organizations: The globe study of 62 societies. New York, NY: Sage publications.

Huizingh, E. K. (2011). Open innovation: State of the art and future perspectives. Technovation, 31(1), 2-9. doi:https://doi.org/10.1016/j.technovation.2010.10.002

Ilies, R., Morgeson, F. P., \& Nahrgang, J. D. (2005). Authentic leadership and eudaemonic well-being: Understanding leader-follower outcomes. The Leadership Quarterly, 16(3), 373-394. doi:https://doi.org/10.1016/j.leaqua.2005 .03 .002

Jackman, M. R. (1994). The velvet glove: Paternalism and conflict in gender, class, and race relations. California, CA: University of California Press. 
Jung, D. I., Chow, C., \& Wu, A. (2003). The role of transformational leadership in enhancing organizational innovation: Hypotheses and some preliminary findings. The Leadership Quarterly, 14(4-5), 525-544. doi:https://doi.org/ 10.1016/s1048-9843(03)00050-x

Kang, J. H., Solomon, G. T., \& Choi, D. Y. (2015). Ceos' leadership styles and managers' innovative behaviour: Investigation of intervening effects in an entrepreneurial context. Journal of Management Studies, 52(4), 531-554. doi:https://doi.org/10.1111/joms.12125

Kastalli, I. V., \& Van Looy, B. (2013). Servitization: Disentangling the impact of service business model innovation on manufacturing firm performance. Journal of Operations Management, 31(4), 169-180. doi:https://doi.org/ 10.1016/j.jom.2013.02.001

Kotter, J. (1998). Cultures and coalitions. rethinking the future: Rethinking business, principles, competition control and complexity, leadership, markets and the world. London, UK: Nicholas Brealey Press.

Kuczmarski, S. S., \& Kuczmarski, T. D. (1995). Values-based leadership. New York, NY: Prentice Hall.

Lerner, J., \& Tirole, J. (2002). Some simple economics of open source. The Journal of Industrial Economics, 50(2), 197-234. doi:https://doi.org/10.1111/1467-6451.00174

Lewin, K., \& Lippitt, R. (1938). An experimental approach to the study of autocracy and democracy: A preliminary note. Sociometry, 1(3/4), 292-300. doi:https://doi.org/10.2307/2785585

Luthar, H. K. (1996). Gender differences in evaluation of performance and leadership ability: Autocratic vs. democratic managers. Sex Roles, 35(5-6), 337-361. doi:https://doi.org/10.1007/bf01664773

Michie, S., \& Gooty, J. (2005). Values, emotions, and authenticity: Will the real leader please stand up? The Leadership Quarterly, 16(3), 441-457. doi:https://doi.org/10.1016/j.leaqua.2005.03.006

Mortara, L., \& Minshall, T. (2011). How do large multinational companies implement open innovation? Technovation, 31(10-11), 586-597. doi:https://doi.org/10.1016/j.technovation.2011.05.002

Nahavandi, A. (1993). Integrating leadership and strategic management in organizational theory. Canadian Journal of Administrative Sciences, 10(4), 297-307. doi:https://doi.org/10.1111/j.1936-4490.1993.tb00035.x

Neider, L. L., \& Schriesheim, C. A. (2011). The Authentic Leadership Inventory (ALI): Development and empirical tests. The Leadership Quarterly, 22(6), 1146-1164. doi:https://doi.org/10.1016/j.leaqua.2011.09.008

Neyer, A.-K., Bullinger, A. C., \& Moeslein, K. M. (2009). Integrating inside and outside innovators: A sociotechnical systems perspective. R\&d Management, 39(4), 410-419.

Ogbonna, E., \& Harris, L. C. (2000). Leadership style, organizational culture and performance: Empirical evidence from UK companies. International Journal of Human Resource Management, 11(4), 766-788.

Oh, D.-S., Phillips, F., Park, S., \& Lee, E. (2016). Innovation ecosystems: A critical examination. Technovation, 54, 1-6. doi:https://doi.org/10.1016/j.technovation.2016.02.004

Osterlind, S. J., Tabachnick, B. G., \& Fidell, L. S. (2001). Spss for window workbook to acompany: Using multivariate statistics.-4th.-tabachnick and fidell. New York, NY: Allyn and Bacon.

Pellegrini, E. K., Scandura, T. A., \& Jayaraman, V. (2010). Cross-cultural generalizability of paternalistic leadership: An expansion of leader-member exchange theory. Group \& Organization Management, 35(4), 391-420. doi: https://doi.org/10.1177/1059601110378456

Png, I. P., Tan, B. C., \& Wee, K.-L. (2001). Dimensions of national culture and corporate adoption of it infrastructure. IEEE Transactions on Engineering Management, 48(1), 36-45. doi:https://doi.org/10.1109/17.913164

Podsakoff, P. M., MacKenzie, S. B., Lee, J.-Y., \& Podsakoff, N. P. (2003). Common method biases in behavioral research: A critical review of the literature and recommended remedies. Journal of Applied Psychology, 88(5), 879.

Punnett, B. J., \& Shenkar, O. (2004). Handbook for international management research. Michigan, MI: University of Michigan Press.

Putri, Y. R. (2015). Transformational leadership and its impact to lecturers intellectual capital factors in Telkom economics and business school Telkom university. International Journal of Business and Administrative Studies, 1(1), 35-41. doi:https://doi.org/10.1037/0021-9010.88.5.879

Rangus, K., Drnovsek, M., \& Di Minin, A. (2013). Proclivity for open innovation: Construct conceptualization and empirical validation. In In Conference of Academy of Management Proceedings, Briarcliff Manor, NY.

Redding, S. G., Norman, A., \& Schlander, A. (1994). The nature of individual attachment to the organization: A review of east asian variations. Handbook of Industrial and Organizational Psychology, 4, 647-688. 
Rego, A., Sousa, F., Marques, C., \& e Cunha, M. P. (2012). Authentic leadership promoting employees' psychological capital and creativity. Journal of business research, 65(3), 429-437.

Rossberger, R. J., \& Krause, D. E. (2017). National culture, heterogeneity and innovation new insights into the relationship between the globe dimensions and national level innovation. GSTF Journal of Law and Social Sciences (JLSS), 2(1), 34-50.

Saputri, M. E., \& Mulyaningsih, H. D. (2016). Blue ocean strategy for creating value innovation: A study over kedai digital in Yogyakarta, Indonesia. Journal of Administrative and Business Studies, 1(1), 14-20. doi:https://doi.org/ 10.20474/jabs-1.1.3

Sarros, J. C., Cooper, B. K., \& Santora, J. C. (2008). Building a climate for innovation through transformational leadership and organizational culture. Journal of Leadership \& Organizational Studies, 15(2), 145-158. doi: https://doi.org/10.1177/1548051808324100

Scott, S. G., \& Bruce, R. A. (1994). Determinants of innovative behavior: A path model of individual innovation in the workplace. Academy of Management Journal, 37(3), 580-607. doi:https://doi.org/10.2307/256701

Shane, S. (1993). Cultural influences on national rates of innovation. Journal of Business Venturing, 8(1), 59-73. doi:https://doi.org/10.1016/0883-9026(93)90011-s

Shane, S. (1995). Uncertainty avoidance and the preference for innovation championing roles. Journal of International Business Studies, 26(1), 47-68.

Silahtaroglu, G., \& Vardarlier, P. (2016). Leaders impact on organizational behavior: A text mining study on universities in Turkey. International Journal of Business and Administrative Studies, 2(2), 52-56. doi:https://doi.org/10.1057/ palgrave.jibs. 8490165

Teece, D. J. (2007). Explicating dynamic capabilities: The nature and microfoundations of (sustainable) enterprise performance. Strategic Management Journal, 28(13), 1319-1350. doi:https://doi.org/10.1007/978-3-642-04898 $-2 \_394$

Triandis, H. C., Kurowski, L. L., \& Gelfand, M. J. (1994). Workplace diversity. New York, NY: Consulting Psychologists Press.

Turner, F. (2008). Romantic automatism: Art, technology, and collaborative labor in cold war America. Journal of Visual Culture, 7(1), 5-26. doi:https://doi.org/10.4135/9781452243405.n2

Van Everdingen, Y. M., \& Waarts, E. (2003). The effect of national culture on the adoption of innovations. Marketing Letters, 14(3), 217-232. doi:https://doi.org/10.1023/a:1027452919403

Von Krogh, G., Nonaka, I., \& Rechsteiner, L. (2012). Leadership in organizational knowledge creation: A review and framework. Journal of Management Studies, 49(1), 240-277. doi:https://doi.org/10.1111/j.1467-6486.2010 .00978.x

Walumbwa, F. O., Avolio, B. J., Gardner, W. L., Wernsing, T. S., \& Peterson, S. J. (2008). Authentic leadership: Development and validation of a theory-based measure. Journal of Management, 34(1), 89-126. doi:https:// doi.org/10.1177/0149206307308913

Wong, C., \& Cummings, G. (2009). Authentic leadership: A new theory for nursing or back to basics? Journal of Health Organization and Management, 23(5), 522-538. doi:https://doi.org/10.1108/14777260910984014 


\begin{tabular}{|c|c|c|c|c|c|c|c|c|c|c|c|c|c|c|c|c|}
\hline $\begin{array}{l}\mathrm{SN} \\
\mathrm{o}\end{array}$ & $\begin{array}{l}\text { Vari- } \\
\text { ables }\end{array}$ & Mean & S.D & 1 & 2 & 3 & 4 & 5 & 6 & 7 & 8 & 9 & 10 & 11 & 12 & 13 \\
\hline 1 & $\begin{array}{l}\text { Org } \\
\text { age }\end{array}$ & 29.85 & 5.495 & & & & & & & & & & & & & \\
\hline 2 & $\begin{array}{l}\text { Hos- } \\
\text { pital } \\
\text { type }\end{array}$ & 1.41 & 0.785 & 0.006 & & & & & & & & & & & & \\
\hline 3 & $\begin{array}{l}\text { No } \\
\text { Spe- } \\
\text { cialist }\end{array}$ & 3.86 & 1.227 & $.361 * *$ & $.218 * *$ & & & & & & & & & & & \\
\hline 4 & $\begin{array}{l}\text { Gen- } \\
\text { der }\end{array}$ & 1.45 & 0.498 & -0.03 & $-.160 * *$ & -0.051 & & & & & & & & & & \\
\hline 5 & $\begin{array}{l}\text { Length } \\
\text { Tenure }\end{array}$ & 2.989 & 3.903 & 0.054 & 0.043 & 0.1 & $-.160^{* *}$ & & & & & & & & & \\
\hline 6 & $\begin{array}{l}\mathrm{T} \\
\text { expe- } \\
\text { rience }\end{array}$ & 4.817 & 4.693 & 0.037 & $.380 * *$ & $.132 *$ & $-.267 * *$ & $.467 * *$ & & & & & & & & \\
\hline 7 & $\begin{array}{l}\text { In- } \\
\text { come }\end{array}$ & 2.24 & 0.788 & -0.055 & $.267 * *$ & -0.01 & $-.240 * *$ & $.310 * *$ & $.689 * *$ & & & & & & & \\
\hline 8 & $\begin{array}{l}\text { Em- } \\
\text { ploy- } \\
\text { ees }\end{array}$ & 300 & 13 & $.421 * *$ & 0.058 & $.578 * *$ & 0.016 & $.128 *$ & $.130^{*}$ & 0.017 & & & & & & \\
\hline 9 & $\begin{array}{l}\mathrm{P}- \\
\text { leadersh }\end{array}$ & $\begin{array}{l}3.639 \\
\text { ip }\end{array}$ & 0.722 & -0.018 & $-.309 * *$ & $-.291 * *$ & $.148 * *$ & $-.121 *$ & $-.316^{* *}$ & $-.254 * *$ & $-.169 * *$ & $(0.78)$ & & & & \\
\hline 10 & $\begin{array}{l}\text { ATH- } \\
\text { Lead- } \\
\text { ership }\end{array}$ & 3.478 & 0.620 & -0.079 & $-.292 * *$ & $-.359 * *$ & 0.091 & -0.092 & $-.331 * *$ & $-.221 * *$ & $-.252 * *$ & $.641 * *$ & $(0.91)$ & & & \\
\hline 11 & $\begin{array}{l}\text { Dem- } \\
\text { Lead- } \\
\text { ership }\end{array}$ & 3.761 & 0.581 & -0.027 & $-.263 * *$ & $-.284 * *$ & $.152 * *$ & $-.197 * *$ & $-.319 * *$ & $-.201 * *$ & $-.112^{*}$ & $.637 * *$ & $.649 * *$ & $(0.76)$ & & \\
\hline 12 & UAVOIL & 3.813 & 0.591 & -0.037 & $-.190 * *$ & $-.232 * *$ & 0.09 & -0.051 & $-.165 * *$ & -0.068 & -0.086 & $.534 * *$ & $.502 * *$ & $.656^{* *}$ & $(0.80)$ & \\
\hline 13 & OSI & 4.744 & 0.878 & $-.135^{*}$ & $-.253 * *$ & $-.359 * *$ & $.134 *$ & -0.102 & $-.288 * *$ & $-.156 * *$ & $-.284 * *$ & $.447 * *$ & $.507 * *$ & $.464 * *$ & $.454 * *$ & $(0.95)$ \\
\hline
\end{tabular}

Note. $N=422, P$-leadership: paternalistic leadership, Dem-leadership: democratic leadership, ATH-leadership: Authentic leadership, UAVOID: uncertainty avoidance, OSI: open service innovation, ${ }^{* * *} p<0.001, * * p<0.01, * p<0.05$ 